\title{
WYKŁADNIA ROZSZERZAJĄCA PRAWA OCHRONY ŚRODOWISKA JAKO SZCZEGÓLNEJ GAŁĘZI PRAWA
}

\section{Prawo ochrony środowiska jako szczególna gałąź prawa}

Jakkolwiek różnie ocenia się samodzielność prawa ochrony środowiska jako odrębnej od innych gałęzi prawa, nie ulega wątpliwości, że prawo ochrony środowiska wykazuje szereg cech charakterystycznych, które odróżniają je od innych dziedzin. Jak wskazuje B. Rakoczy, „nawet jeżeli poprzestać jedynie na stwierdzeniu, że prawo ochrony środowiska jest jedynie kompleksową gałęzią prawa, a nie gałęzią prawa z własną metodą regulacji stosunków społecznych, to i tak poza sporem pozostaje pewna odrębność prawa ochrony środowiska w ramach systemu prawa"1. Zaczynając od względów aksjologicznych, w przypadku prawa ochrony środowiska cechą charakterystyczną jest większa koncentracja na wartościach (które zresztą mają specyficzną naturę) aniżeli ma to miejsce $\mathrm{w}$ innych dziedzinach prawa. Podkreśla się, że „zasięg współczesnego rozumienia i odczuwania przez ludzi, a także dostrzegalna skala widocznego wpływu zanieczyszczeń na globalne i lokalne środowisko zbliżają prawo ochrony środowiska do podstawowych wartości etycznych bardziej niż $\mathrm{w}$ wielu innych regulacjach. Jeśli przyjmiemy przekonanie, iż prawo wywodzi się z regulacji zagadnień typowo egzystencjalnej natury i że od zarania cywilizacji doświadczenie życiowe było nie tylko źródłem, ale i nakazem, to współczesne potrzeby regulacji i stany środowiska stymulujące te potrzeby nasycone są motywacjami aksjologicznymi niezależnie od wyrazistości

* Dr, Uniwersytet Jagielloński; e-mail: iprzybojewska@gmail.com.

1 B. Rakoczy, Prawo ochrony środowiska w styku z innymi obszarami systemu prawa, [w:] P. Korzeniowski (red.), Zagadnienia systemowe prawa ochrony środowiska, Łódź 2015, s. 70. 
sposobu ich wyrażania w prawie" ${ }^{\prime 2}$. Odmienna jest też rola aksjologicznych motywacji prawodawcy $\mathrm{w}$ zakresie ochrony środowiska, ponieważ nie tylko leżą one u podstaw regulacji, ale poza wiedzą sozologiczną stanowią bodźce do ciągłego rozwoju prawa ochrony środowiska. Rzutuje to na bardzo dynamiczny charakter norm z tej dziedziny, co podkreślał M. Górski, pisząc, że „przepisy związane z ochroną środowiska są mimo wszystko nadal pewnego rodzaju nowościa, ale nowością wciąż dość żywiołowo się rozwijająca, obejmującą swoim zasięgiem coraz szerszy zakres zagadnień, chociaż tempo tego rozwoju jest zmienne, w oczywisty sposób zależy też od postępów wiedzy dotyczącej środowiska i uwarunkowań środowiskowych działań prowadzonych przez człowieka" ${ }^{\prime 3}$. Jednocześnie uznaje się, że granice prawa ochrony środowiska są płynne ${ }^{4}$, a jego zakres opisuje się jako „wszechogarniający” (ang. all-embracing) ${ }^{5}$. W doktrynie podnosi się, iż „pojęcie środowiska, tak jak je ujmuje prawo pierwotne UE oraz akty prawa pochodnego, obejmuje zarówno środowisko naturalne, jak też środowisko będące wytworem działalności człowieka. Elementami tego pojęcia są: człowiek, fauna, flora, gleba, woda, powietrze, klimat, krajobraz, jak też zasoby materialne i dziedzictwo kulturalne, naturalne otoczenie i zasoby naturalne, a także zasoby wodne. Pojęcie środowiska obejmuje również elementy otoczenia społecznego człowieka, dotyczące społecznych warunków życia jednostki i społeczeństwa. Prawo tak rozumianego środowiska reguluje również sprawy odpadów i zaopatrzenia w energię" ${ }^{\prime \prime}$. Z pewnością aktualne jest stwierdzenie, że z uwagi na obszerność problematyki prawa ochrony środowiska trudno jest precyzyjnie opisać jego strukturę i komponenty ${ }^{7}$.

Poza wspomnianym mocnym oddziaływaniem względów aksjologicznych $^{8}$, w ramach prawa ochrony środowiska doszukać się można

2 J. Boć, Prawo ochrony środowiska jako prawo publiczne, [w:] P. Korzeniowski (red.), Zagadnienia systemowe prawa ochrony środowiska, Łódź 2015, s. 20.

3 M. Górski, System prawa ochrony środowiska, [w:] P. Korzeniowski (red.), Zagadnienia systemowe prawa ochrony środowiska, Łódź 2015, s. 36.

4 Zob. D. McGillivray, J. Holder, Locating EC Environmental Law, „Yearbook of Environmental Law" 2001, s. 157.

5 Zob. L. Krämer, EU Environmental Law, Londyn 2012, s. 1-4.

6 M.M. Kenig-Witkowska, Prawo środowiska Unii Europejskiej. Zagadnienia systemowe, Warszawa 2011, s. 13.

7 Zob. L. Karski, Znaczenie prawa ochrony środowiska, "Studia Ecologiae et Bioethicae” 2011, nr 9, s. 93.

8 Zastosowane wyróżnienia w tekście niniejszego artykułu zostały dokonane przez autorkę. 
wielu odrębności, które w zdecydowany sposób oddzielają tę dziedzinę od innych sfer prawa. W tym kontekście L. Karski wyróżnia „przedmiot $\underline{\text { regulacji - czyli ochrona otoczenia przyrodniczego człowieka, swoiste }}$ zasady, czyli przykładowo zasada zanieczyszczający płaci oraz swoiste instytucje prawne, jak przykładowo pozwolenie zintegrowane, czy udział społeczeństwa" ${ }^{\prime \prime}$ Idąc dalej, można zaryzykować twierdzenie, że przykład swoistych instrumentów, jakimi posługuje się prawo ochrony środowiska, stanowią instrumenty rynkowe, takie jak handel emisjami czy zielone certyfikaty. Wspomniane instrumenty cechują się tym, że w ich ramach „zarówno koszt korzystania z zasobów środowiska, jak i wynagrodzenie za pożądaną aktywność będą kształtowane przez podaż i popyt. [...] Wysokość kosztów i zysków zewnętrznych określa rynek. Na przykład ekonomiczna wartość środowiskowa dokładana do ceny usługi lub towaru w przypadku jednostek emisyjnych będzie ustalana przez popyt na uprawnienia i podaż uprawnień. W odniesieniu do instrumentów rynkowych cena jest kształtowana przez podaż i popyt na rynku. Oznacza to, iż w przypadku instrumentów rynkowych, w stosunku do środków finansowo-prawnych, zwiększa się stopień ryzyka gospodarczego, lecz także zwiększa się szansa na niższą cenę np. uprawnień" ${ }^{\prime 10}$. W doktrynie podnosi się również istnienie specyficznych podstaw odpowiedzialności $\underline{\mathrm{w} \text { prawie ochrony środowiska }}{ }^{11}$. Z uwagi na tak daleko idące odmienności, jakie zaznaczają się w tej sferze, można byłoby przyjąć, że prawo ochrony środowiska jest szczególną gałęzią prawa, pod warunkiem wszakże przyjęcia dla określenia pojęcia gałęzi prawa odpowiedniej konwencji terminologicznej, inkorporującej kryteria mieszane, abstrahujące od metody regulacji. Jak bowiem słusznie wskazują J. Nowacki i Z. Tobor, „o podziale prawa na takie lub inne gałęzie (działy) decyduje przyjęcie określonej konwencji, i to niezależnie od tego, czy jest to konwencja szacowna, wielowiekowa, czy też zaledwie postulowana dzisiaj"12. Dynamiczny rozwój prawa ochrony środowiska będzie - moim zdaniem - prowadził do wzrostu jego znaczenia i pogłębiania się różnic pomiędzy tą dziedziną a innymi sferami prawa. Nie bez znaczenia w tym zakresie jest fakt, że

9 L. Karski, Znaczenie prawa..., s. 94.

10 L. Karski, Wdrażanie instrumentów rynkowych prawa ochrony środowiska, [w:] M. Rudnicki, A. Haładyj, K. Sobieraj (red.), Dekada harmonizacji w prawie ochrony środowiska, Lublin 2011, s. 419.

11 Zob. J. Boć, Prawo ochrony..., s. 26.

12 J. Nowacki, Z. Tobor, Wstęp do prawoznawstwa, Warszawa 2012, s. 99. 
obecnie prawo ochrony środowiska w Polsce w istotnej (i coraz większej) części obejmowanej materii nie jest wynalazkiem rodzimym, a rezultatem wdrożenia do polskiego porządku prawnego unijnych dyrektyw. Stąd też trudno, także rozważając kwestię odrębności prawa ochrony środowiska, traktować regulacje unijnego porządku prawnego w tym zakresie jako byt abstrakcyjny, oderwany od unormowań prawa polskiego. W sytuacji, gdy na kształt regulacji środowiskowych przyjmowanych w Polsce w zasadniczym zakresie rzutuje unijny porządek prawny, specyfika tego porządku prawnego także, w jakimś stopniu, będzie oddziaływać na pojmowanie i stosowanie prawa ochrony środowiska w Polsce. Rozważania dotyczące odrębności prawa ochrony środowiska i możliwości jego sklasyfikowania jako samodzielnej gałęzi prawa mają jednak walor pragmatyczny o tyle, o ile z opisanej specyfiki prawa ochrony środowiska wynikać będą określone konsekwencje, mające przełożenie na praktykę stosowania tego prawa. W ocenie autorki, taką praktyczną konsekwencję stanowi okoliczność, że wspomniana specyfika otwiera prawo ochrony środowiska na wykładnię rozszerzającą - polegającą na porównaniu rozumienia przepisu prawnego uzyskanego za pomocą różnych dyrektyw interpretacyjnych i wyborze rozumienia szerszego, niż wynikałoby to z czysto językowej analizy - w większym zakresie i w inny sposób, niż dzieje się to w przypadku pozostałych dziedzin prawa.

\section{Miejsce wykładni rozszerzającej w polskim porządku prawnym}

Wykładnia rozszerzająca w oczywisty sposób wiąże się ze zwiększeniem roli pozajęzykowych dyrektyw wykładni. Tymczasem zasadniczo w polskim systemie prawa, i w ogóle w modelu kontynentalnym, fundamentalne znaczenie nadaje się właśnie językowym dyrektywom wykładni. Jak wskazano w doktrynie: „Rola podstawowa danych reguł oznacza zastosowanie ich $w$ pierwszej kolejności oraz modelowo najmocniejszy wpływ na wynik wykładni. W kulturze prawa stanowionego zwykle taką rolę odgrywają reguły językowe i systemowe, bowiem wykładnia jest tu dokonywana na gruncie przepisów prawnych. Iedynie pewne konstrukcje szczególne (odesłania pozasystemowe, normy programowe, zasady prawa) oraz szczególne sytuacje (luki w prawie, sprzeczności normatywne) powoduja tu modyfikacje modelu ogólnego. Z kolei rola kontekstowa 
oznacza bezpośrednie odnoszenie wyników wykorzystania reguł podstawowych do kontekstu aksjologicznego czy celowościowego i funkcjonalnego (w pewnym zakresie także systemowego), lokując się w drugiej kolejności zastosowania w procesie wykładni. Natomiast rola weryfikacyjna, pojawiająca się zwykle w trzeciej odsłonie procesu wykładni, występuje w sytuacji stwierdzenia konieczności uzupełnienia wyników zastosowania reguł wcześniejszych lub, w wersji mocniejszej, skorygowania tego wyniku"13. Tym samym, włączenie pozajęzykowych dyrektyw interpretacyjnych, co do zasady, następuje dopiero w drugim i trzecim kroku $\mathrm{w}$ procesie interpretacji przepisu prawnego. Dyrektywy takie mają istotne znaczenie, pełniąc rolę kontekstową i weryfikacyjną, jednak nie podważają prymatu wykładni językowej, która - poza wyjątkowymi przypadkami - odgrywa rolę dominującą i decydującą. Koresponduje to ze spostrzeżeniem M. Zielińskiego, który podniósł, że w ostatnich latach Sąd Najwyższy „w przytłaczającej większości przypadków, nawet w sytuacji uzyskania jednoznaczności językowej przepisu poddawał go również interpretacji systemowej i funkcjonalnej. Zwykle po to, by wzmocnić rezultat językowy, ale częściowo i po to, by sprawdzić, czy jednoznaczność uzyskana nie prowadzi do sprzeczności w systemie prawa (np. z normami hierarchicznie wyższymi albo z zasadami prawa), albo też czy nie burzy powszechnie akceptowanych społecznie wartości"14. Drugorzędna pozycja wykładni aksjologicznej, celowościowej czy funkcjonalnej w systemie prawa kontynentalnego uzasadniana jest przede wszystkim względami pewności prawa (prymat wykładni językowej w sposób szczególny podkreślany bywa w orzecznictwie w odniesieniu do dziedzin prawa szczególnie ingerujących w prawa i wolności jednostki albo też nakładających na jednostkę szczególne obowiązki, jak prawo karne czy prawo podatkowe). Pole dla wykładni rozszerzającej w polskim porządku prawnym wydaje się zatem bardzo wąskie - de facto ograniczone tylko do przypadków klauzul generalnych czy podobnych konstrukcji - o ile są one wprost wyrażone $\mathrm{w}$ przepisach obowiązującego prawa. Podobnie byłoby również $\mathrm{w}$ ramach polskiego prawa ochrony środowiska, pomimo omówionych uprzednio odmienności w tej dziedzinie, w szczególności w postaci silniejszej obecności i roli pierwiastka aksjologicznego.

13 A. Kalisz, L. Leszczyński, B. Liżewski, Wykładnia prawa. Model ogólny a perspektywa Europejskiej Konwencji Praw Człowieka i prawa Unii Europejskiej, Lublin 2011, s. 28.

14 M. Zieliński, Wykładnia prawa. Zasady - reguły-wskazówki, Warszawa 2017, s. 54. 


\section{Wykładnia rozszerzająca $w$ unijnym porządku prawnym}

Okoliczności ulegają jednak zmianie, gdy weźmiemy pod uwagę, że ochrona środowiska stanowi także sferę aktywności Unii Europejskiej, na zasadzie kompetencji dzielonych z państwami członkowskimi. Oznacza to, że określona (przeważająca) część polskiego prawa ochrony środowiska stanowi pokłosie prawodawstwa unijnego, a konkretnie przejaw i skutek implementacji dyrektyw unijnych. Jest to o tyle istotne, że dyrektywy unijne w myśl art. 288 Traktatu o funkcjonowaniu Unii Europejskiej ${ }^{15}$ wiążą tylko co do rezultatu, który ma być osiągnięty, pozostawiają jednak organom krajowym swobodę wyboru formy i środków. Unijna polityka w dziedzinie środowiska naturalnego jest zdominowana przez dyrektywy, a w doktrynie pojawiły się twierdzenia, że polityka ta charakteryzuje się minimalną harmonizacją przez przyjmowanie dyrektyw o ogólnych, elastycznych celach $^{16}$. Nie jest to jednak do końca prawda, ponieważ wiele dyrektyw z tej dziedziny zawiera niekiedy bardzo szczegółowe postanowienia, które nie pozostawiają państwom członkowskim znacznego pola manewru. Bardzo często postanowienia dyrektywy determinują treść prawa krajowego w zakresie daleko wykraczającym poza "rezultat”, a obejmującym także „formę i środki”. Dzieje się tak zarówno z przyczyn leżących po stronie prawodawcy unijnego (często posługującego się dyrektywami idącymi dalej niż te będące przejawem harmonizacji minimalnej), a niekiedy prawodawcy krajowego, który za najbezpieczniejszą metodę wdrożenia unijnych dyrektyw zdaje się nierzadko uznawać podejście copy-paste. Nie ulega natomiast wątpliwości, że już sama charakterystyka dyrektyw, wymagających implementacji do krajowego porządku prawnego, otwiera prawo krajowe na względy aksjologiczne i celowościowe. Jak podkreśla się w doktrynie, „,w przypadku prawa unijnego [...] system źródeł prawa jest dość specyficzny - skomplikowany, niepodobny do systemów źródeł prawa państw członkowskich. Istotna rola judykatury oraz włączanie zasad prawa, preambuł czy rozumowań inferencyjnych do rekonstrukcji nie znosi reguły pierwszeństwa korzystania $\mathrm{z}$ reguł językowych, ale wprowadza na ten pierwszy etap wykładni również argumenty aksjologiczne, celowościowe czy funkcjonalne"17. Co

15 Wersja skonsolidowana Traktatu o funkcjonowaniu Unii Europejskiej, Dz. Urz. UE z 30.03.2010, C 83 , s. 47-200.

16 Zob. P. Wennerås, The Enforcement of EC Environmental Law, Oxford 2007, s. 72.

17 A. Kalisz, L. Leszczyński, B. Liżewski, Wykładnia prawa..., s. 196-197. 
ważne, prawidłowa inkorporacja względów aksjologicznych i celowościowych obecnych w dyrektywach do implementujących te dyrektywy regulacji krajowych ma istotne znaczenie w kontekście ważkiej roli Trybunału Sprawiedliwości Unii Europejskiej, który de facto orzeka na zasadzie precedensów, mimo iż de lege lata traktaty unijne nie przewidują przyznania orzecznictwu sądowemu funkcji źródła prawa. Taka cokolwiek paradoksalna sytuacja jest jednak nieunikniona, jeżeli weźmiemy pod uwagę, że prawo unijne zasadniczo charakteryzuje się nagromadzeniem odwołań do względów aksjologicznych. Przy takim ukształtowaniu regulacji nie jest w ogóle możliwe poprzestanie w procesie ich interpretacji na wykładni literalnej, której dokonywanie można byłoby pozostawić organom stosującym to prawo w konkretnych sprawach. Gdyby natomiast pozostawić takim organom dokonywanie wykładni celowościowej, pojawiłoby się poważne niebezpieczeństwo w odniesieniu do zakładanej harmonizacji porządków prawnych państw członkowskich. Dlatego wyjątkowa rola Trybunału Sprawiedliwości jest konsekwencją takiego a nie innego sposobu sformułowania prawa unijnego.

Silna obecność względów aksjologicznych uwidacznia się w prawie unijnym na wiele różnych sposobów. Po pierwsze, bardzo często w aktach prawa unijnego (w szczególności, ale nie tylko, w dyrektywach) określa się cele danej regulacji. Jak podkreślono w doktrynie: „Najmocniejszą rolę odgrywają cele wyraźnie zaznaczone w tekście normatywnym. Modelowo najbardziej dotyczy to określenia celu danego aktu czy jego fragmentu lub bardziej konkretnej instytucji bezpośrednio w przepisie prawnym. Nie jest to jednak zabieg spotykany często. Zwykle taki cel musi być odkodowywany z innych sformułowań przepisów (odwołujących się np. do przedmiotu danej regulacji) lub kojarzony z preambułą aktu normatywnego (jeżeli ta jest sformułowana oraz jeśli zawiera kontekst teleologiczny). [...] Im bardziej bezpośrednie i sformalizowane jest źródło identyfikacji celu prawodawczego, tym modelowo mocniejsza jest rola reguł celowościowych w procesie wykładni"18. Tymczasem w polskim porządku prawnym wskazywanie celów $\mathrm{w}$ unormowaniach prawnych stanowi raczej wyjątek niż regułę, co przyczynia się do tego, że prymat wykładni literalnej pozostaje $\mathrm{w}$ zasadzie niepodważalny.

Wartości przyświecające prawodawcy unijnemu są także wyrażane poprzez bezpośrednie wskazywanie jego aksjologicznych preferencji.

18 Tamże, s. 56. 
Przykładowo Unia Europejska w ramach przewodzenia międzynarodowym wysiłkom na rzecz walki ze zmianami klimatycznymi starała się wykazać, że dekarbonizacja jest kompatybilna z innymi ważnymi wartościami, takimi jak bezpieczeństwo energetyczne ${ }^{19}$. Rola wartości w interpretacji prawa unijnego podkreślana jest także przez Trybunał Sprawiedliwości poprzez zasadę autonomicznego rozumienia pojęć zawartych w prawie unijnym, czego skutkiem jest „nadawanie pojęciom znaczeń szerszych, niż wynikałoby to z czysto językowej analizy danego terminu lub sformułowania" 20 .

Po czwarte, zasadniczy brak skutku bezpośredniego dyrektyw uzupełniany jest o zasadę wykładni prawa krajowego w sposób zgodny z prawem unijnym. Prawo krajowe należy bowiem interpretować „w świetle brzmienia i celu dyrektywy". Zasada wykładni prawa krajowego zgodnej $\mathrm{z}$ prawem unijnym jest trwale zakorzeniona $\mathrm{w}$ orzecznictwie Trybunału Sprawiedliwości, który wywodzi ją z zasady lojalnej i szczerej współpracy. Warto w tym miejscu wskazać na orzeczenie w sprawie van Colson and Ka$m a n n^{21}$, gdzie stwierdzono, że dla urzeczywistnienia celów dyrektywy „do sądu krajowego należy, na ile to jest możliwe w ramach swobodnej oceny, przyznanej mu przez prawo krajowe, dokonanie takiej wykładni i takie stosowanie przepisów wydanych w celu wykonania dyrektywy, które będą zgodne z wymogami prawa unijnego". Podobne zastosowanie zasady wykładni prounijnej Trybunał wskazał w orzeczeniu w sprawie Faccini Dori22, dodatkowo przesądzając o konieczności naprawienia szkód, jakie zostały wyrządzone jednostkom z powodu braku transpozycji dyrektywy, o ile nie ma możliwości osiągnięcia celu zakładanego w dyrektywie $\mathrm{w}$ drodze wykładni zgodnej. Jeszcze dalej Trybunał poszedł w orzeczeniu w sprawie Pfeiffer23, w myśl którego sąd krajowy przy stosowaniu przepisów prawa

19 Zob. C.F. Parker, C. Karlsson, The European Union as a Global Climate Leader: Confronting Aspiration with Evidence, „International Environmental Agreements: Politics, Law and Economics" 2017, nr 4, s. 450.

20 A. Kalisz, L. Leszczyński, B. Liżewski, Wykładnia prawa..., s. 200.

${ }^{21}$ Wyrok Trybunału z dnia 10 kwietnia 1984 r., sprawa 14/83, Sabine von Colson $i$ Elisabeth Kamann p. Land Nordrhein-Westfalen, Zbiory Orzecznictwa Trybunału Europejskiego 1984, s. 01891.

22 Wyrok Trybunału z dnia 14 lipca 1994 r., sprawa C-91/92, Paola Faccini Dori p. Recreb Srl, Zbiory Orzecznictwa Trybunału Europejskiego 1994, s. I-03325.

23 Wyrok Trybunału z dnia 5 października 2004 r., sprawy połączone C-397/01 do C-403/01, Bernhard Pfeiffer (C-397/01), Wilhelm Roith (C-398/01), Albert Süß (C-399/01), Michael 
krajowego przyjętych w celu transpozycji zobowiązań przewidzianych w dyrektywie, powinien brać pod uwagę całość norm prawa krajowego oraz interpretować je w najszerszym możliwym zakresie w świetle brzmienia i celu tej dyrektywy, aby osiągnąć rozwiązanie zgodne z celem przez nią wytyczonym. W orzeczeniu w sprawie Wagner Miret ${ }^{24}$ Trybunał stwierdził, że „sądy krajowe powinny domniemywać zamiar pełnego wykonania zobowiązań płynących z dyrektyw i dopiero po stwierdzeniu, że przepisy krajowe w żaden sposób nie dają się pogodzić z dyrektywa, uchylać się od ich zastosowania". Podobnie w orzeczeniu w sprawie Marleasing 25 obowiązek dokonywania wykładni zgodnej został rozciągnięty na przepisy krajowe, które nie implementują dyrektyw, a także na przepisy istniejące przed wejściem w życie dyrektywy. Enigmatyczne sformułowanie granic dokonywania wykładni zgodnej "tak dalece, jak to tylko możliwe" (as far as possible) samo $\mathrm{w}$ sobie zdaje się przesądzać o powinności stosowania zasady wykładni prounijnej przed realizacją zasady pierwszeństwa, czyli odmową zastosowania normy prawa krajowego niezgodnej z prawem unijnym i zastosowaniem $\mathrm{w}$ jej miejsce odpowiedniej normy prawa unijnego przez krajowy sąd lub organ administracji ${ }^{26}$. Jak wskazuje M. Smolak, „realizacja obowiązku wykładni zgodnej z dyrektywami może być postrzegana jako niezbędny etap zapewnienia dyrektywom efektywności w krajowym porządku prawnym, jeden $\mathrm{z}$ instrumentów realizacji «obowiązku rezultatu» $\mathrm{z}$ art. 288 akapit trzeci TFUE, część procesu implementacji dyrektyw"27. W ten sposób interpretacja prawa krajowego jest nakierowywana na łączne stosowanie reguł wykładni literalnej i celowościowej ${ }^{28}$. Dzieje się tak

Winter (C-400/01), Klaus Nestvogel (C-401/01), Roswitha Zeller (C-402/01) i Matthias Döbele (C-403/01) p. Deutsches Rotes Kreuz, Kreisverband Waldshut eV, Dz. Urz. UE z 4.12.2004, C 300, s. 2-3.

24 Wyrok Trybunału z dnia 16 grudnia 1993 r., sprawa C-334/92, Teodoro Wagner Miret p. Fondo de garantía salarial, Zbiory Orzecznictwa Trybunału Europejskiego 1993, s. I-06911.

25 Wyrok Trybunału z dnia 13 listopada 1990 r., sprawa C-106/89, Marleasing SA p. La Comercial Internacional de Alimentacion SA, Zbiory Orzecznictwa Trybunału Europejskiego 1990, s. I-04135.

26 Zob. I. Przybojewska, Konstytucyjna zasada przychylności procesowi integracji europejskiej w świetle ewolucji unijnego modelu ustrojowego, [w:] S. Dudzik, N. Półtorak (red.), Prawo Unii Europejskiej a prawo konstytucyjne państw członkowskich, Warszawa 2013, s. 209-210.

${ }_{27}$ M. Smolak, Wykładnia celowościowa z perspektywy pragmatycznej, Warszawa 2012, s. 408 .

28 M. Domańska, Implementacja dyrektyw unijnych przez sądy krajowe, Warszawa 2014, s. 222 . 
w odniesieniu do wszystkich sfer aktywności Unii Europejskiej, w ramach których współwystępują kompetencje Unii i państw członkowskich (kompetencje dzielone), a zatem także w odniesieniu do ochrony środowiska. Na obecnym etapie rozwoju prawa unijnego (i przy głębi jego oddziaływania), w tych sferach aktywności nie da się już - w mojej ocenie - dokonywać sztywnego odseparowania treści prawa unijnego od treści prawa krajowego.

Wszystkie powyższe elementy, odnoszące się do sposobu ukształtowania prawa unijnego oraz wykładni tego prawa dokonywanej przez Trybunał Sprawiedliwości, uzasadniają twierdzenie, że wykładnia rozszerzająca jest bardzo często stosowanym sposobem interpretacji prawa unijnego. Poprzez implementację dyrektyw do krajowego porządku prawnego, ten sposób wykładni, stosowany na poziomie prawa unijnego, rzutuje zarówno na ukształtowanie, jak i interpretacje prawa krajowego.

\section{Wpływ wykładni rozszerzającej na stosowanie prawa ochrony środowiska}

Wykładnia rozszerzająca w połączeniu z wykładnią celowościową jest w coraz większym zakresie stosowana przez Trybunał Sprawiedliwości Unii Europejskiej, celem zapewnienia efektywności i ochrony zasad unijnej polityki w dziedzinie środowiska ${ }^{29}$. Jest to poniekąd wymuszone dynamicznym charakterem tej dziedziny prawa, determinowanym $\mathrm{w}$ podstawowej mierze postępem wiedzy naukowej. Z tego powodu ogólne sformułowania, używane w dyrektywach, często muszą być interpretowane w sposób progresywny. Istnieją jednak także inne przyczyny takiego stanu rzeczy. Jeden z istotniejszych problemów polega na tym, że - jak zauważył L. Krämer - wszyscy zgadzają się co do zastosowania zrównoważonego rozwoju, wysokiego poziomu ochrony czy zasad prewencji i przezorności, jednak trudność zasadza się na sposobie zastosowania tych celów i zasad do poszczególnych problemów, jak na przykład zmiana klimatu ${ }^{30}$.

29 P. Wennerås, A Progressive Interpretation of the Environmental Liability Directive, „Journal of European Environmental and Planning Law" 2005, nr 4, s. 257.

30 Zob. L. Krämer, Differentiation in EU Environmental Policy, „European Environmental Law Review" 1999, nr 4, s. 140. 
Dlatego niejednokrotnie poprzestawanie na ogólnych sformułowaniach jest wynikiem braku możliwości osiągnięcia dalej idącego konsensusu.

Bardzo wiele orzeczeń Trybunału Sprawiedliwości Unii Europejskiej, wydanych na kanwie unijnej polityki w dziedzinie środowiska naturalnego, odwołuje się do wykładni rozszerzającej - dlatego nie jest możliwe ich całościowe zbadanie w niniejszym artykule. Celowe wydaje się jednak zanalizowanie ich reprezentatywnych przykładów, tak aby można było dokonać rekonstrukcji najczęstszych powodów i sposobów odwoływania się do wykładni rozszerzającej w unijnym orzecznictwie.

Jednym z orzeczeń dotyczących prawa ochrony środowiska, w którym Trybunał zdecydował się zastosować wykładnię rozszerzająca, było orzeczenie w sprawie Ecologistas en Acción-CODA przeciwko Ayuntamiento de Madrid ${ }^{31}$. Wyrok ten dotyczył oceny oddziaływania przedsięwzięć, a w tym konkretnym przypadku kwestii, czy należy przeprowadzić ocenę oddziaływania w sytuacji, gdy przedsięwzięcie w postaci budowy obwodnicy miasta Madrytu zostało podzielone na kilkanaście niezależnych przedsięwzięć, które - jeżeli by brać je każde z osobna - nie spełniałyby kryteriów obligujących do przeprowadzenia takiej oceny oddziaływania. W orzeczeniu tym Trybunał zastosował wykładnię rozszerzającą na wiele różnych sposobów. Po pierwsze, odwołał się do autonomicznego rozumienia pojęć występujących w prawie unijnym w stosunku do ich interpretacji w prawie krajowym. Jak wskazano: „Według Ayuntamiento de Madrid obwodnica będąca przedmiotem postępowania przed sądem krajowym jest drogą miejską. Otóż zmieniona dyrektywa nie dotyczy tego rodzaju drogi w załącznikach I i II, które wymieniają jedynie autostrady, drogi szybkiego ruchu i drogi. Pojęcia te nie są ponadto zdefiniowane, z wyjątkiem, w odniesieniu do pojęcia dróg szybkiego ruchu, odesłania do definicji podanej w umowie. Zdaniem pozwanego w postępowaniu przed sądem krajowym w braku wyraźnego określenia tych pojęć prawo hiszpańskie transponujące zmienioną dyrektywę przejęło z niej dokładne pojęcia. Ponieważ nie figurują w niej drogi miejskie, mógł on uważać, że przedsięwzięcia dotyczące zmiany takiej drogi nie wchodzą w zakres zmienionej dyrektywy, a w konsekwencji nie musiały być poddane ocenie wpływu na środowisko. Nie można przyjąć tego twierdzenia. Należy

31 Wyrok Trybunału z dnia 25 lipca 2008 r., sprawa C-142/07 Ecologistas en Acción-CODA przeciwko Ayuntamiento de Madrid, Zbiory Orzecznictwa Trybunału Europejskiego 2008, s. I-06097. 
przypomnieć, iż Trybunał wskazywał wielokrotnie, że zakres stosowania dyrektywy 85/337 oraz zmienionej dyrektywy jest bardzo szeroki (zob. podobnie wyroki: z dnia 24 października 1996 r. w sprawie C-72/95 Kraaijeveld i in., Rec. s. I-5403, pkt 31, z dnia 16 września 1999 r. w sprawie C-435/97 WWF i in., Rec. s. I-5613, pkt 40 oraz z dnia 28 lutego 2008 r. w sprawie C-2/07 Abraham i in., dotychczas nieopublikowany w Zbiorze, pkt 32). Sprzeczne z celem zmienionej dyrektywy byłoby zatem wyłaczenie z zakresu jej stosowania wszelkich przedsięwzięć dotyczących dróg miejskich tylko na tej podstawie, że wśród przedsięwzięć wymienionych w jej załącznikach I i II dyrektywa ta nie wymienia wyraźnie przedsięwzięć dotyczacych dróg tego rodzaju. Z dotychczas utrwalonego orzecznictwa wynika, że państwa członkowskie winny wykonywać zmieniona dyrektywę, jak i dyrektywę 85/337, w sposób odpowiadajacy w pełni stawianym przez nia wymogom, z uwzględnieniem jej podstawowego celu, którym jest, zgodnie $z$ jej art. 2 ust. 1, poddawanie, przed wydaniem zezwolenia, przedsięwzięć, które moga powodować znaczace skutki dla środowiska naturalnego, w szczególności ze względu na ich charakter, rozmiar lub lokalizacje, ocenie w zakresie ich oddziaływania na środowisko (zob. podobnie m.in. wyroki: z dnia 19 września 2000 r. w sprawie C-287/98 Linster, Rec. s. I-6917, pkt 52 oraz z dnia 23 listopada 2006 r. w sprawie C-486/04 Komisja przeciwko Włochom, Zb. Orz. s. I-11025, pkt 36).W konsekwencji należy zatem uznać, że przedsięwzięcia dotyczące dróg miejskich wchodzą w zakres stosowania zmienionej dyrektywy" ${ }^{\prime 2}$.

Z przytoczonego fragmentu orzeczenia wynika więc, że Trybunał interpretuje pojęcia występujące $\mathrm{w}$ dyrektywie dotyczącej ocen oddziaływania na środowisko w taki sposób, aby ich interpretacja odzwierciedlała cele określane przez tę dyrektywę, uwidaczniające się m.in. w szerokim zakresie jej zastosowania. W tym samym orzeczeniu Trybunał odwołał się do konieczności uwzględniania, w ramach przeprowadzanej oceny oddziaływania na środowisko, wszystkich skutków pojawiających się na wszystkich etapach realizacji przedsięwzięcia. Trybunał zauważył, że „w taki sam sposób jak dyrektywa 85/337 zmieniona dyrektywa nawiązuje do ogólnej oceny wpływu przedsięwzięć lub ich zmiany na środowisko. Sprzeczne i zawężające $\mathrm{w}$ stosunku do tego podejścia byłoby uwzględnienie $w$ zakresie oceny skutków wywieranych na środowisko naturalne przez przedsiewzięcie lub jego zmiane jedynie bezpośrednich skutków

32 Tamże. 
planowanych robót jako takich, z pominięciem skutków wywieranych na środowisko naturalne, które moga wynikać z użytkowania i eksploatacji systemów bedacych rezultatem tych robót (w odniesieniu do dyrektywy 85/337 zob. ww. wyrok w sprawie Abraham i in., pkt 42 i 43). W odniesieniu do lokalizacji przedsięwzięć załącznik III pkt 2 lit. g) i h) zmienionej dyrektywy wymienia obszary gęsto zaludnione jak również krajobrazy o znaczeniu historycznym, kulturalnym lub archeologicznym jako kryteria selekcji, jakie państwa członkowskie powinny uwzględnić zgodnie $\mathrm{z}$ art. 4 ust. 3 tej dyrektywy podczas przeprowadzania badania indywidualnego lub ustalania progów bądź kryteriów przewidzianych w ust. 2 tego artykułu, w celu ustalenia, czy przedsięwzięcie powinno podlegać ocenie. Te kryteria selekcji mogą dotyczyć również przedsięwzięć dróg miejskich (zob. podobnie ww. wyrok z dnia 16 marca 2006 r. w sprawie Komisja przeciwko Hiszpanii, pkt 79) [...] Poza tym, takie jak w art. 3 dyrektywy 85/337, zawarte w art. 3 zmienionej dyrektywy wyliczenie elementów, jakie należy wziąć pod uwagę, takich jak skutki przedsięwzięcia miedzy innymi dla istot ludzkich, fauny i flory, gleby, wód, powietrza lub dziedzictwa kultury, samo świadczy o tym, że skutkami wywieranymi na środowisko naturalne, umożliwienie oceny, których jest celem, zmienionej dyrektywy, są nie tylko skutki przewidywanych robót, lecz również i przede wszystkim skutki przedsięwzięcia, które ma zostać zrealizowane (zob. podobnie ww. wyrok w sprawie Abraham i in., pkt 44)"33. Trybunał opowiedział się zatem za postrzeganiem przedsięwzięć w sposób całościowy, w czym można dostrzec refleks zasady integracji.

Zdecydowanie dalej w zastosowaniu wykładni rozszerzającej Trybunał Sprawiedliwości poszedł w orzeczeniu w sprawie Inter-Environnement Bruxelles ASBL, Pétitions-Patrimoine ASBL i Atelier de Recherche et d'Action Urbaines ASBL przeciwko Région de Bruxelles-Capitale ${ }^{34}$. Orzeczenie to dotyczyło kwestii, czy obowiązkiem przeprowadzenia strategicznej oceny oddziaływania na środowisko objęte są także dokumenty, które uchylają akty planistyczne. O ile bowiem odnośna dyrektywa przesądzała

33 Tamże.

34 Wyrok Trybunału z dnia 22 marca 2012 r., sprawa C-567/10 Inter-Environnement Bruxelles ASBL, Pétitions-Patrimoine ASBL i Atelier de Recherche et d'Action Urbaines ASBL przeciwko Région de Bruxelles-Capitale, opublikowany w elektronicznym Zbiorze Orzeczeń, http://curia.europa.eu/juris/document/document.jsf;jsessionid=50F5D77DCD2CE04F99 4C83535A26607C?text $=\&$ docid $=120781 \&$ pageIndex=0\&doclang=PL\&mode $=1$ st\&dir $=\&$ occ $=$ first\&part=1\&cid=799641 [dostęp: 29.10.2018 r.]. 
o zastosowaniu jej postanowień do określonych kategorii aktów, a także aktów je modyfikujących, o tyle próżno szukać w jej treści odniesienia do aktów uchylających. Wbrew treści dyrektywy, Trybunał Sprawiedliwości stwierdził, że „majac na uwadze cel dyrektywy 2001/42, którym jest zapewnienie wysokiego poziomu ochrony środowiska, przepisy wyznaczające zakres stosowania tej dyrektywy, a w szczególności zawierające definicje aktów, które ona obejmuje, należy interpretować rozszerzajaco. W tym kontekście nie jest wykluczone, że częściowe lub całkowite uchylenie planu lub programu może mieć znaczący wpływ na środowisko, ponieważ może ono oznaczać modyfikację zagospodarowania zaplanowanego na danych obszarach. Wynika $z$ tego, że ze względu na cechy i skutki aktów uchylajacych taki plan lub program uznanie tych aktów za wyłaczone z zakresu zastosowania dyrektywy 2001/42 byłoby sprzeczne z celami realizowanymi przez ustawodawce unijnego i mogłoby naruszać w części skuteczność tej dyrektywy" ${ }^{35}$. Tym samym Trybunał, dokonując wykładni rozszerzającej ze względu na cele dyrektywy, de facto dokonał wykładni contra legem - o ile bowiem pojęcia określające dane kategorie dróg publicznych rzeczywiście mogą być interpretowane w różny sposób, gdyż jest to kwestia przyjęcia określonej konwencji, o tyle trudno tego rodzaju twierdzenie wysunąć w odniesieniu do sytuacji, w której dyrektywa wprost mówi o dokumentach z danej kategorii i ich modyfikacjach.

Do jeszcze dalej idącego zastosowania wykładni rozszerzającej doszło przy okazji wydania orzeczenia Trybunału Sprawiedliwości w sprawie Landelijke Vereniging tot Behoud van de Waddenzee i Nederlandse Vereniging tot Bescherming van Vogels przeciwko Staatssecretaris van Landbouw, Natuurbeheer en Visserij ${ }^{36}$, dotyczącego interpretacji przepisów odnoszących się do ochrony obszarów Natura 2000. Orzeczenie to dotyczyło zagadnienia oceny pragmatycznego zastosowania wymogu poddania ocenie oddziaływania planów lub przedsięwzięć. Odnośna dyrektywa posługiwała się bowiem ogólnym sformułowaniem, uruchamiającym wymóg poddania planu lub przedsięwzięcia ocenie wtedy, gdy mogły one znacząco oddziaływać na środowisko. Sformułowanie to tworzyło istotny problem

35 Tamże.

36 Wyrok Trybunału z dnia 7 września 2004 r., sprawa C-127/02 Landelijke Vereniging tot Behoud van de Waddenzee $i$ Nederlandse Vereniging tot Bescherming van Vogels przeciwko Staatssecretaris van Landbouw, Natuurbeheer en Visserij, Zbiory Orzecznictwa Trybunału Europejskiego 2004, s. I-07405. 
w zakresie stwierdzenia, w jakich konkretnie okolicznościach należy taką ocenę przeprowadzić. Trybunał Sprawiedliwości wskazał, że „art. 6 ust. 3 zdanie pierwsze dyrektywy siedliskowej uzależnia wymóg dokonania odpowiedniej oceny planu lub przedsięwzięcia od przesłanki polegającej na zaistnieniu prawdopodobieństwa lub ryzyka, że ten plan lub przedsięwzięcie będzie oddziaływać na dany teren w istotny sposób. Mając w szczególności na uwadze zasadę ostrożności, będącą jedną z podstaw polityki Wspólnoty w dziedzinie środowiska naturalnego, stawiającej sobie za cel wysoki poziom ochrony zgodnie z art. 174 ust. 2 zdanie pierwsze WE, w świetle którego należy dokonywać wykładni dyrektywy siedliskowej, ryzyko takie ma miejsce wówczas, gdy na podstawie obiektywnych informacji nie można wykluczyć, że przedmiotowy plan lub przedsięwzięcie będzie oddziaływać na dany teren w istotny sposób (zob. analogicznie w szczególności wyrok z dnia 5 maja 1998 r. w sprawie C-180/96 Zjednoczone Królestwo przeciwko Komisji, Rec. str. I-2265, pkt 50, 105 i 107). Taka wykładnia przesłanki, od zaistnienia której uzależnione jest przeprowadzenie odpowiedniej oceny skutków planu lub przedsięwzięcia dla danego terenu, na podstawie której, w przypadku wątpliwości co do nie wystąpienia ewentualnych istotnych oddziaływań należy dokonać takiej oceny, umożliwia w sposób skuteczny na uniknięcie udzielania pozwoleń na plany lub przedsięwzięcia wpływające niekorzystnie na dany teren i przyczynia się w ten sposób do urzeczywistnienia głównego celu dyrektywy siedliskowej, polegającego na zapewnieniu różnorodności biologicznej poprzez ochronę siedlisk przyrodniczych oraz dzikiej fauny i flory, zgodnie z trzecim motywem i art. 2 ust. 1 tej dyrektywy" ${ }^{\prime \prime}$. Innymi słowy, Trybunał dokonał odwrócenia ciężaru dowodu w zakresie interpretacji przesłanki możliwego znaczącego wpływu planu lub przedsięwzięcia na obszary chronione, uzasadniając to względami proefektywnościowymi. Przyjęcie, że istnieje możliwość istotnego oddziaływania w przypadku, gdy na podstawie obiektywnych informacji nie można tego wykluczyć, skutkuje bowiem w praktyce powstaniem domniemania, że plan lub przedsięwzięcie mogą $\mathrm{w}$ istotny sposób oddziaływać na dany teren. W takim podejściu widoczne jest wzięcie pod uwagę zasady ostrożności, przywołanej zresztą wprost przez Trybunał. Zasada ostrożności (przezorności) jest zasada, która w najbardziej wyważonej wersji wykładni wskazuje na niezbędność podejmowania działań w celu przeciwdziałania 
negatywnym skutkom danej aktywności, jeżeli nie ma dostatecznej naukowej pewności co do występowania takich konsekwencji, aczkolwiek istnieją przesłanki pozwalające przyjąć możliwość ich wystąpienia ${ }^{38}$. Wydaje się, że to właśnie uwzględnienie tej zasady doprowadziło Trybunał do zastosowania wykładni rozszerzającej nawet w przypadkach, gdy zastosowanie takiej wykładni niosło ze sobą tak poważne konsekwencje, jak wykładnia contra legem czy odwrócenie ciężaru dowodu. Zasada przezorności jest bowiem zasadą o szczególnym znaczeniu dla unijnej polityki w dziedzinie środowiska naturalnego. Bazuje ona na dynamicznym charakterze wspomnianej sfery aktywności Unii Europejskiej, determinując jej kształt i zapewniając swoisty margines bezpieczeństwa dla działalności człowieka - zgodnie z koncepcją zrównoważonego rozwoju.

\section{Zakończenie}

Przeprowadzane rozważania pozwalają na wysunięcie wniosku, że wykładnia rozszerzająca prawa ochrony środowiska, dokonywana na szczeblu prawa unijnego, ale w istotnym zakresie rzutująca na kształt $\mathrm{i}$ interpretację prawa polskiego, motywowana bywa względami dwojakiego przynajmniej rodzaju. Po pierwsze, wykładnia rozszerzająca, będąca wynikiem zastosowania wykładni celowościowej i wykładni aksjologicznej, jest zarazem wykładnią proefektywnościową. W niektórych przypadkach nie sposób uniknąć wrażenia, że Trybunał Sprawiedliwości w drodze twórczej wykładni przepisów dyrektyw wypełnia luki pozostawione przez prawodawcę unijnego, które mogłyby zagrozić efektywności przyjmowanych instrumentów. Tego rodzaju rola wykładni rozszerzającej nie jest specyficzna tylko dla prawa ochrony środowiska. Jednak w ramach prawa ochrony środowiska rola i zakres zastosowania wykładni rozszerzającej ulegają istotnemu wzmocnieniu poprzez zastosowanie zasady przezorności, w dość daleko idącej wersji interpretacji. Otwarte pozostaje pytanie, czy i w jakim zakresie, przy uwzględnieniu okoliczności konkretnego przypadku i specyfiki danej normy, względy te mogą zrównoważyć

38 Szerzej na temat zasady przezorności, zob. I. Przybojewska, Znaczenie transeuropejskich sieci energetycznych dla zapewnienia bezpieczeństwa energetycznego, Warszawa 2017, s. 300-325, wraz z przytoczoną tam literaturą. 
widoczny w tym kontekście uszczerbek dla pewności prawa. Przyzwolenie na wzrastającą rolę wykładni rozszerzającej w odniesieniu na przykład do norm programowych czy innych norm o ogólniejszym charakterze, nie będzie jednocześnie oznaczać takiej akceptacji w stosunku do norm nakładających obowiązki obwarowane sankcjami na podmioty prywatne.

Słowa kluczowe: wykładnia, prawo ochrony środowiska, wykładnia celowościowa, wykładnia rozszerzająca

\section{Bibliografia}

Boć J., Prawo ochrony środowiska jako prawo publiczne, [w:] P. Korzeniowski (red.), Zagadnienia systemowe prawa ochrony środowiska, Łódź 2015, s. 17-27.

Domańska M., Implementacja dyrektyw unijnych przez sady krajowe, Warszawa 2014.

Górski M., System prawa ochrony środowiska, [w:] P. Korzeniowski (red.), Zagadnienia systemowe prawa ochrony środowiska, Łódź 2015, s. 29-41.

Kalisz A., L. Leszczyński, B. Liżewski, Wykładnia prawa. Model ogólny a perspektywa Europejskiej Konwencji Praw Człowieka i prawa Unii Europejskiej, Lublin 2011.

Karski L., Wdrażanie instrumentów rynkowych prawa ochrony środowiska, [w:] M. Rudnicki, A. Haładyj, K. Sobieraj (red.), Dekada harmonizacji w prawie ochrony środowiska, Lublin 2011, s. 411-432.

Karski L., Znaczenie prawa ochrony środowiska, "Studia Ecologiae et Bioethicae” 2011, nr 9, s. 85-97.

Kenig-Witkowska M.M., Prawo środowiska Unii Europejskiej. Zagadnienia systemowe, Warszawa 2011.

Krämer L., Differentiation in EU Environmental Policy, „European Environmental Law Review" 1999, nr 4, s. 133-140.

Krämer L., EU Environmental Law, Londyn 2012.

McGillivray D., J. Holder, Locating EC Environmental Law, „Yearbook of Environmental Law" 2001, s. 139-171.

Nowacki J., Z. Tobor, Wstęp do prawoznawstwa, Warszawa 2012.

Parker C.F., C. Karlsson, The European Union as a Global Climate Leader: Confronting Aspiration with Evidence, "International Environmental Agreements: Politics, Law and Economics" 2017, nr 4, s. 445-461.

Przybojewska I., Konstytucyjna zasada przychylności procesowi integracji europejskiej w świetle ewolucji unijnego modelu ustrojowego, [w:] S. Dudzik, N. Półtorak (red.), Prawo Unii Europejskiej a prawo konstytucyjne państw członkowskich, Warszawa 2013, s. 197-212. 
Przybojewska I., Znaczenie transeuropejskich sieci energetycznych dla zapewnienia bezpieczeństwa energetycznego, Warszawa 2017.

Rakoczy B., Prawo ochrony środowiska w styku z innymi obszarami systemu prawa, [w:] P. Korzeniowski (red.), Zagadnienia systemowe prawa ochrony środowiska, Łódź 2015, s. 69-79.

Smolak M., Wykładnia celowościowa z perspektywy pragmatycznej, Warszawa 2012. Wennerås P., A Progressive Interpretation of the Environmental Liability Directive, „Journal of European Environmental and Planning Law" 2005, nr 4, s. 257-267. Wennerås P., The Enforcement of EC Environmental Law, Oxford 2007.

Zieliński M., Wykładnia prawa. Zasady - reguły - wskazówki, Warszawa 2017.

\section{EXTENSIVE INTERPRETATION OF ENVIRONMENTAL LAW AS A SPECIFIC BRANCH OF LAW}

\section{Sum mary}

The subject of the present article is an analysis of the role of extensive interpretation within the framework of environmental law. Although, depending on adopted attitude with regard to terminology, independence of environmental law as a separate branch of law is viewed divergently in the doctrine, there are no doubts as to possession, by the environmental law, of an array of characteristic features that differentiate it amongst other fields of law. In particular, there may be mentioned presence of its own principles (like „polluter pays” principle or principle of prevention, as well as precautionary principle) or use of marketbased instruments. Environmental law is also the field which is being shaped both under the influence of law of the European Union, as well as the influence of domestic legal order. That leads to a situation in which within the framework of environmental law there is a clash of various trends concerning interpretation of law, i.e. primacy of literal interpretation, traditionally assumed with regard to Polish law, and, on the other hand, emphasis put on teleological interpretation, demonstrated in jurisprudence of the European Court of Justice. The latter trend is strengthened by the impact of principles and values which lie at the heart of environmental law. That leads to interesting results in legal interpretation.

Key words: interpretation, environmental law, teleological interpretation, extensive interpretation 


\section{ИНТЕРПРЕТАЦИЯ, КОТОРАЯ РАСПОСТРАНЯЕТ ПРАВА ОХРАНЫ ОКРУЖАЮЩЕЙ СРЕДЫ КАК ОСОБЕННОЙ ВЕТКИ ПРАВА}

\section{Резюме}

Предметом данной статьи является анализ роли интерпретации, которая распространяется в рамках права охраны окружающей среды. Однако, в зависимости от принятой терминологической конвенции по-разному оценивается самостоятельность права охраны окружающей среды, как отдельной от других веток права, однако, не поддается сомнению, что право охраны окружающей среды предоставляет ряд характерных признаков, которые отличают его от других отраслей. Данное является, в частности, присутствие собственных принципов (как принцип „загрязнитель платит" или принцип профилактики и принцип предосторожности) или исподьзование рыночных инструментов охраны окружающей среды. Это также есть область, которая формируется как под влиянием Евросоюза, так и государственного правопорядка. Данное влечет за собой то, что в рамках права охраны окружающей среды настает стирание разных тенденций, которые касаются интерпретации права, это есть, с одной стороны, примат буквадьной интерпретации, традиционно принятого относительно польского права, а с другой стороны, акцентирует на целенаправленности интерпретации, отображенного в вынесенных решений Суда Европейского союза. Последняя тенденция поддается укреплению путем отделения принципов и ценностей, которые лежат в оснований права охраны окружающей среды, что ведет к интересным интерпретационным результатам.

Ключевые слова: интерпретация, право охраны окружающей среды, целенаправленная интерпретация, обширная интерпретация 
